\title{
Recurrent neck pain as a variant of migraine: description of four cases
}

\author{
Milena De Marinis, Neri Accornero
}

\begin{abstract}
Four patients who had recurrent attacks of idiopathic unilateral neck pain and tenderness of the ipsilateral carotid artery are described. Two patients had never had headache. The other two had migraine without aura. All patients had dilatation of extracranial arteries during the attacks (telethermographic examination), oculosympathetic hypofunction (pupillary tests), and positive responses to vasoactive drugs which are commonly used for migraine treatment. Recurrent neck pain involving the carotid artery seems to be a variant form of migraine that may occur alone or in association with headache in patients with involvement of extracranial arteries.
\end{abstract}

$(\mathcal{F}$ Neurol Neurosurg Psychiatry 1997;62:669-670)

Department of

Neurological Sciences,

"La Sapienza"

University, Rome,

Italy

M De Marinis

N Accornero

Correspondence to:

Dr Milena De Marinis, Via A

Bertoloni 1/E, 00197 Rome,

Italy.

Received 19 September 1996

and in final revised form

28 January 1997

Accepted 14 February 1997
Keywords: carotidynia; migraine; neck pain; oculosympathetic system; telethermography

We present four patients, collected over eight years, in whom recurrent attacks of idiopathic unilateral neck pain and tenderness of the ipsilateral carotid artery were likely to be a variant of migraine. Tables 1 and 2 show the main clinical features of the pain and the results of the investigations performed in the four patients.
Case 1

A 25 year old woman had a two year history of recurrent attacks of right sided neck pain. Ipsilateral carotid tenderness and neck swelling were associated and persisted during the next 12 hours.

\section{Case 2}

A 32 year old woman had had recurrent attacks of left sided unilateral neck pain for three years. She had no history of headache and began to have frequent attacks of neck pain (two or three a week) after three months of oral contraceptive intake. When oral contraceptives were interrupted, the attacks of pain became rare and less severe (one or two a month) and disappeared within the next three months. No specific diagnosis was formulated. The patient came to our attention because of an attack of neck pain after a renewed intake of oral contraceptives. After stopping the contraceptives, the patient subsequently had only six attacks of left sided neck pain of less severe intensity and not associated with any pupillary abnormalities over a two year follow up period.

\section{Case 3}

A 38 year old man who had had migraine without aura ${ }^{1}$ for eight years came to our attention because of the occurrence of a new

Table 1 Clinical features of the four patients

\begin{tabular}{|c|c|c|c|c|}
\hline & Case 1 & Case 2 & Case 3 & Case 4 \\
\hline Family history of migraine & Positive & Positive & Positive & Positive \\
\hline Localisation of pain & $\begin{array}{l}\text { Right side of the neck } \\
\text { (carotid artery region) }\end{array}$ & $\begin{array}{l}\text { Left side of the neck } \\
\text { (spreading to the hemicranium) }\end{array}$ & $\begin{array}{l}\text { Right side of the neck } \\
\text { (carotid artery region) }\end{array}$ & $\begin{array}{l}\text { Bilateral (> right side) } \\
\text { (carotid artery regions) }\end{array}$ \\
\hline Type of pain & Pulsating & Pulsating & Pulsating & Pulsating \\
\hline Intensity of pain & Severe & Severe & Severe & Middle/severe \\
\hline \multicolumn{5}{|l|}{ Aggravation of pain } \\
\hline Photophobia/phonophobia & $\begin{array}{l}\text { Yes } \\
\text { Yes }\end{array}$ & $\begin{array}{l}\text { No } \\
\text { Yes }\end{array}$ & $\begin{array}{l}\text { Yes } \\
\text { Yes }\end{array}$ & $\begin{array}{l}\text { Yes } \\
\text { Yes }\end{array}$ \\
\hline Nausea/vomiting & $\begin{array}{l}\text { Yes } \\
\text { No }\end{array}$ & $\begin{array}{l}\text { Yes } \\
\text { No }\end{array}$ & $\begin{array}{l}\text { Yes } \\
\text { Yes }\end{array}$ & $\begin{array}{l}\text { Yes } \\
\text { Yes }\end{array}$ \\
\hline Other autonomic symptoms & No & $\begin{array}{l}\text { Left sided miosis and ptosis } \\
\text { (only first attack) }\end{array}$ & No & No \\
\hline $\begin{array}{l}\text { Duration of untreated attacks } \\
\text { Frequency of attacks }\end{array}$ & $\begin{array}{l}4-6 \text { hours } \\
1-3 \text { per month }\end{array}$ & $\begin{array}{l}48 \text { hours } \\
\text { Variable } \\
\text { (related to intake of }\end{array}$ & $\begin{array}{l}\text { 4-7 hours } \\
5-7 \text { per month }\end{array}$ & $\begin{array}{l}5-9 \text { hours } \\
6-8 \text { per month }\end{array}$ \\
\hline & & contraceptives) & & \\
\hline \multirow{5}{*}{$\begin{array}{l}\text { Other types of head pain } \\
\text { Efficacy of symptomatic drugs } \\
\text { Ergotamine (suppositories) } \\
\text { Sumatriptan (subcutaneous injection) } \\
\text { Efficacy of prophylactic treatment } \\
\text { calcium antagonists }\end{array}$} & No & No & Right sided migraine & Bilateral migraine \\
\hline & & & & \\
\hline & Yes & Yes & Yes & Yes \\
\hline & Yes & Yes & Yes & Yes \\
\hline & Not given & Not given & Yes & Yes \\
\hline
\end{tabular}


Table 2 Results of investigations in the four patients

\begin{tabular}{|c|c|c|c|c|}
\hline & Case 1 & Case 2 & Case 3 & Case 4 \\
\hline \multirow[t]{2}{*}{$\begin{array}{l}\text { Exclusion of other diseases } \\
\text { (ears, nose, throat, thyroid) } \\
\text { Routine laboratory data } \\
\text { Neurological signs } \\
\text { Ultrasonic angiodoppler } \\
\text { Brain MRI } \\
\text { MR angiography } \\
\text { Telethermography during an attack } \\
\text { Bilateral increase in temperature }\end{array}$} & $\begin{array}{l}\text { Yes } \\
\text { Normal } \\
\text { No } \\
\text { Normal } \\
\text { Normal } \\
\text { Normal }\end{array}$ & $\begin{array}{l}\text { Yes } \\
\text { Normal } \\
\text { No } \\
\text { Normal } \\
\text { Normal } \\
\text { Normal }\end{array}$ & $\begin{array}{l}\text { Yes } \\
\text { Normal } \\
\text { No } \\
\text { Normal } \\
\text { Normal } \\
\text { Normal }\end{array}$ & $\begin{array}{l}\text { Yes } \\
\text { Normal } \\
\text { No } \\
\text { Normal } \\
\text { Normal } \\
\text { Normal }\end{array}$ \\
\hline & $\begin{array}{l}\text { > In the neck and also } \\
\text { involving the temporal, } \\
\text { periocular and perioral } \\
\text { regions }\end{array}$ & $\begin{array}{l}>\text { On the left side of the neck, } \\
\text { also involving the temporal, } \\
\text { periocular and perioral } \\
\text { regions }\end{array}$ & $\begin{array}{l}>\text { On the right side of } \\
\text { the neck and face }\end{array}$ & $\begin{array}{l}>\text { On the right side of } \\
\text { the neck face and } \\
\text { frontal regions }\end{array}$ \\
\hline $\begin{array}{l}\text { Timing temperature/pain } \\
\text { Pupillary tests during an attack } \\
5 \% \text { tyramine test }\end{array}$ & No & No & No & No \\
\hline $\begin{array}{l}\text { (postganglionic sympathetic deficit) } \\
1 \% \text { Phenylephrine test }\end{array}$ & Right side & Left side & Right side & Right side \\
\hline (adrenoceptor supersensitivity) & No & No & Right side & No \\
\hline
\end{tabular}

type of pain. During his last attack of right sided headache, he had had pain involving the regions of the ipsilateral carotid artery. Carotid tenderness and neck swelling were also present. When examined by us, he was pain free, but carotid tenderness and neck swelling were still present and persisted during the next 24 hours. Various investigations excluded a secondary form of pain. During three years of follow up, the patient presented attacks of neck pain, sometimes associated with migraine attacks.

\section{Case 4}

A 28 year old man was seen by us because of the development of a migraine-like headache. His attacks responded to the International Headache Society (IHS) criteria for migraine without aura ${ }^{1}$ except for the fact that the pain also involved the neck and was associated with ipsilateral carotid tenderness and neck swelling that often persisted after cessation of pain. During four years of follow up the patient continued to present attacks of headache associated with neck pain.

\section{Discussion}

We have described four patients who had recurrent attacks of idiopathic unilateral neck pain and tenderness of the ipsilateral carotid artery. Two had never had headache and the other two had migraine without aura. ${ }^{1}$ These patients presented dilatation of extracranial arteries during the attacks, oculosympathetic hypofunction, and positive responses to vasoactive drugs, all signs found in patients with migraine.

It has been reported that the extracranial arteries may dilate in patients with migraine and that the distention may contribute to the perception of pain. ${ }^{2}$ The presence of carotid artery pain has not, however, been specifically investigated in patients with involvement of the extracranial arteries. In all our patients, vasodilatation of extracranial arteries was associated with neck pain, but the extracranial dilatation did not coincide with the localisation and timing of the pain.

As in migraine, ${ }^{3}$ our patients had vascular changes associated with pupillary alterations indicating sympathethic hypofunction. Horner's syndrome may occur in various conditions involving the carotid artery, such as thrombosis, fibromuscular dysplasia, arteritis, dissecting aneurysm, and surgical intervention to the carotid artery. ${ }^{4-6}$ In these cases, the pupillary dysfunction is due to anatomical damage to the pericarotid sympathetic plexus, which supplies the pupil. In our patients, oculosympathetic hypofunction may have been caused by functional damage to the sympathetic fibres due to the dilatation and swelling of the carotid artery. The finding that the pupillary alterations occurred only ipsilaterally to the painful side, in which the involvement of the carotid artery was more pronounced, seems to support this interpretation.

The similarity between "unilateral recurrent neck pain" and migraine is suggested by various factors including family history of migraine, the presence of photophobia, the triggering effects of oral contraceptives, the efficacy of symptomatic and prophylactic treatments used for migraine, and by the association of the two types of pain (neck pain and migraine pain) in two cases. These patients, however, did not fulfill the IHS classification. ${ }^{1}$ Recurrent neck pain is not in fact mentioned with reference to migraine and the term carotidynia is used by the IHS classification to indicate an idiopathic disease with a self limiting course. ${ }^{1}$ Our cases, as well as others ${ }^{7-10}$ suggest that recurrent attacks of neck pain, whether associated or not with headache, may be a variant form of migraine.

1 Headache Classification Committee of the International Headache Society: classification and diagnostic criteria for headache disorders, cranial neuralgias, and facial pain. Cephalalgia 1988;8(suppl 7): 19-20; 46-9.

2 Drummond PD, Lance JW. Extracranial vascular changes and the source of pain in migraine headache. Ann Neurol 1983;13:32-7.

3 Drummond PD. Disturbances in ocular sympathetic function and facial blood flow in unilateral migraine headache. F Neurol Neurosurg Psychiatry 1990;53:121-5.

4 West TET, Davies RJ, Kelly RE. Horner's syndrome and headache due to carotid artery disease. BMF 1976;i: 818-20.

5 Mokri B, Sundt TM, Houser W. Spontaneous internal carotid dissection, hemicrania, and Horner's syndrome. Arch Neurol 1979;36:677-80.

6 De Marinis M, Zaccaria A, Faraglia V, Fiorani P, Maira G, Agnoli A. Post-endarterectomy headache and the role of the oculosympathetic system. $\mathcal{f}$ Neurol Neurosurg Psychiatry 1991;54:314-7.

7 Lovshin L L. Vascular neck pain; a common syndrome seldom recognized. Cleveland Clinic Quarterly 1960;27:5-13.

8 Roseman DM. Carotidynia-a distinct syndrome. Arch Otolaryngol 1967;85:81-4.

9 Raskin NH, Prusiner S. Carotidynia. Neurology 1977;27: 43-6.

10 De Marinis M. Recurrent neck pain as a variant of migraine: a case report. Neurology 1996;46:269-70. 